О. О. Дідур, Ю. Л. Кульбачко, М. І. Кришень

Дніпровський начіональний університет імені Олеся Гончара

\title{
ЗООГЕННІ ТЕНДЕНЦІЇ БУФЕРНОЇ ЗДАТНОСТІ ГРУНТУ ЯК СКЛАДОВА ЕКОЛОГІЧНОЇ РЕАБІЛІТАЦІЇ УРБОГРРУНТУ В МЕЖАХ ПАРКОВОЇ ЗОНИ МЕГАПОЛІСА
}

Розглянуто пертинентну роль грунтових сапрофагів на прикладі трофометаболічної функції представників дощових черв'яків (Lumbricidae) у формуванні буферних властивостей міських грунтів на території зони рекреації - парку «Зелений гай» (м. Дніпро, Україна). 3'ясовано, що кислотно-основна буферна смність грунтових новоутворень зоогенного походження (копролітів дощових черв'яків) статистично достовірно більша, ніж вихідних грунтів (урбогрунт, верхній гумусований шар чорнозему звичайного) у кислотному діапазоні зовнішнього навантаження на 22,9 \%, у лужному - на 18,4 \%, в сумарному кислотно-лужному відношенні - на 20,6 \%. Отже, такі грунтові сапрофаги як дощові черв'яки в умовах мегаполіса у зоні рекреації на території міських парків у зелених насадженнях виступають активним фактором пертиненції, одним із природних чинників екологічної реабілітації урбогрунтів та оптимізації їх екологічних властивостей.

Ключові слова: пертинентна функція сапрофагів, урбогрунт, буферна здатність грунту, кислотно-основна буферність, потенціал елементів родючості, міський парк, мегаполіс.

О. А. Дидур, Ю. Л. Кульбачко, М. И. Крышень

Днепровский национальный университет имени Олеся Гончара

\section{ЗООГЕННЫЕ ТЕНДЕНЦИИ БУФЕРНОЙ СПОСОБНОСТИ ПОЧВЫ КАК СОСТАВЛЯЮЩАЯ ЭКОЛОГИЧЕСКОЙ РЕАБИЛИТАЦИИ УРБАНОЗЕМА В ГРАНИЦАХ ПАРКОВОЙ ЗОНЫ МЕГАПОЛИСА}

Рассмотрена пертинентная роль почвенных сапрофагов на примере трофометаболической функции представителей дождевых червей (Lumbricidae) в формировании буферных свойств городских почв на территории зоны рекреации - парка «Зеленый гай» (г. Днепр, Украина). Установлено, что кислотно-основная буферная емкость почвенных новообразований зоогенного происхождения (копролитов дождевых червей) статистически достоверно больше, чем исходных почв (урбопочва, верхний гумусованный слой чернозема обыкновенного) в кислотном интервале воздействия на $22,9 \%$, в щелочном - на $18,4 \%$, в суммарном кислотноосновном отношении - на $20,6 \%$. Таким образом, дождевые черви в условиях мегаполиса в зоне рекреации на территории городских парков в зеленых насаждениях выступают активным фактором пертиненции, одним из естественных механизмов экологической реабилитации урбопочв и оптимизации их экологических свойств.

Ключевые слова: пертинентная функция сапрофагов, урбопочва, буферная способность почвы, кислотно-основная буферность, потенциал элементов плодородия, городской парк, мегаполис.

O. O. Didur, Yu. L. Kulbachko, M. I. Krushen

Oles Honchar Dnipro National University

\section{ZOOGENEOUS TRENDS OF SOIL BUFFER CAPACITY \\ AS A CONSTITUENT OF ENVIRONMENTAL REHABILITATION OF URBAN SOIL WITHIN MEGAPOLIS PARK ZONE}

Ecoservice role of soil saprophagues, in particular trophometabolic function of earthworms (Lumbricidae), in formation of urban soils buffer capacity and as markers of

(C) O. O. Didur, Yu. L. Kulbachko, M. I. Krushen, 2017 
soil fertility elements potential within recreation park "Zeleny gai" (city Dnipro, Ukraine) was evaluated. Earthworms can be considered as geochemically active functional group: they participate in physical and biochemical transformation of dead plant material, paddling of it with soil, interfere physical, chemical and biological soil properties, which are limiting productivity and soil fertility and also define further character of biological elements (and energy) turnover in the system "soil-plant". It was demonstrated that in above-ground ecosystems earthworms not only contributing into biogenic migration processes, redistributing carbon, nitrogen and other biogenic elements between phytocenosis and soil, they participating actively in the mechanism of stabilization and soil fertility formation by improving its buffer capacity. Buffer capacity defines that share of soil potential, which supports immobilization (deponation) and mobilization (release or loss) of certain elements of fertility - first of all mineral elements essential for plants, productive moisture, heat energy of soil, gas composition of soil air.

Urbanization is one of the main character feature of the modern human civilization. In conditions of steadily increasing cities' population and its densification artificial green territories able to compensate gaps in plant cover of urban lands are in great demand. Park is a specific type of urban space, which has important recreation function, at the same time, parks as big vegetation massives play important microclimatic and sanitary - hygienic role, improving the quality and comfort of the environment for citizens who are distant for the nature in their everyday life. They enrich personal and individual aspect of living environment for modern citizen, increase level of culture, leisure time quality, esthetically oriented harmonized space contributes into upbringing of personal perception, making it more subtle and this ultimately reflects on the lifestyle of the modern citizen.

Park soils within megapolises territory are their integral components and this defines conditions of growth and development for green plants. Such processes as soil profile disturbance, overdensification of root-inhabitant layer, limitation of volume available for the plants' root system development, loss of nutrients, humus, microelements and fertility, contamination with heavy metals and other toxicants, changing in soil acidity and alkalinity, decrease in soil microflora and fauna diversity, accumulation of the litter on the surface can be listed among other ecologically negative consequences for soils in the conditions of urban environment. Thus, optimization of the ecological properties of green plantations' and parks' soils in megapolis environment, as part of general aim of effective urban management is an actual problem. Results obtained during the present study disclose one of the aspects of environmental creation (pertinent) role of soil saprophages in the revitalization of edaphotopes of the park zones in megapolises. Positive pertinent role of saprophages in the formation of buffer properties of urbansoils within recreation zones on the example of city park soil is identified.

To evaluate the contribution of the products of tropho-metabolic activity of saprophagous (coprolites) on the example of earthworms into acidic-base ( $\mathrm{pH}$ ) buffer capacity of urbansoils of the park zone within the plot planted with Norway maple (Acer platanoides L.) trees, soil and coprolites samples were collected. Soil was sampled in $0-10 \mathrm{~cm}$ depth, fresh coprolites - from the soil surface. Buffer acid-base capacity of coprolites and urban soils was determined according to Arrhenius method, which is based on $\mathrm{pH}$ measurements of soil solutions after addition of weak acidic and basic solutions. Acid-base buffer capacity of studied soils and new soil formations (coprolites) was evaluated according to "buffer area" within acidic and base intervals of the chemical load. Numerical integration method was used to calculate the area, employing Simpson formula. Actual soil solutions acidity measurements $(\mathrm{pH})$, substrate without buffer and studied samples were performed in three repeats.

Is was established that acid-base buffer capacity of new soil formations of zoogenic origin (earthworms coprolites) statistically significantly higher than for initial soil (urbansoil, upper humified layer of Calcic Chernozem) within the acidic diapason on $22,9 \%$, in sum acidic-base relation - on 20,6\%. This promotes ecological state of green plantations on the urban soils within park areas and recreation zone edaphotopes revitalization. Thus soil saprophagues, such as earthworms, in the conditions of magapolises in the recreation zones within the territories of city parks' green plantations is a major factor of pertinention and one of the natural factors of ecological rehabilitation of urban soils and actively realize such ecosystem services as fertility improvement, contribution into nutrients turnover, erosion protection and support optimization of human living and recreation environment.

Keywords: pertinent function of saprophagous, urbansoil, buffer capacity of soil, acid-base buffering, fertile elements potential, city park, megapolis. 
Здоровий, родючий грунт - національне надбання. Проте на території будьякого міста не залишається грунту як природно-історичного органо-мінерального тіла. Природні непошкоджені грунти залишилися лише у вигляді островків у міських лісах і лісопарках. На переважній частині мегаполісів виникли специфічні грунтоподібні тіла - урбогрунти і урбаноземи, які відрізняються від природних грунтів як структурою і властивостями, так і своїми функціями $[7 ; 15 ; 18]$.

До екологічно негативних наслідків, яких зазнає грунт на урбанізованій території, можна віднести порушення грунтового профілю, ущільнення кореневого шару та обмеження об'єму розвитку кореневої системи рослин, виснаження грунтів на живильні речовини, гумус, мікроелементи, забруднення важкими металами та іншими токсикантами, зміна кислотності та лужності, скорочення різноманіття грунтової мікрофлори та грунтових безхребетних [19; 20; 33]. Саме грунт, як невід'ємний компонент паркових зон на території урбосистем, обумовлює умови росту й розвитку зелених насаджень у мегаполісах і виконує важливі екологічні функції.

Основним елементом будь-якого парку мегаполіса є зелені насадження. Вони, як складова частина міського ландшафту, пом'якшують і облагороджують міські забудови, а також мають санітарно-гігієнічну, рекреаційну, ландшафтно-архітектурну та естетичну значимість [5]. Оскільки такі ділянки є місцем відпочинку людей і знаходяться у складних екологічних умовах середовища, вони постійно зазнають впливу підвищеного рекреаційного та антропогенного навантаження і втрачають при цьому свою стійкість. Тому для території мегаполісів, особливо для їх паркових зон, завжди виникає гостра потреба створення умов для відновлення, відтворення й оптимізації як екологічних властивостей грунту, так і деревних насаджень у цілому.

У поліпшенні екологічних властивостей грунту важлива роль серед тваринного населення належить тваринам - екосистемним «інженерам» [24-26], які в результаті своєї педотурбаційної і трофічної активності беруть участь у формуванні структури грунту, в найголовнішому біохімічному грунтовому процесі - гуміфікації, і в кінцевому рахунку - віталізації і натуралізації едафотопів. Екосистемні «інженери» впливають на темпи розкладання відмерлих рослинних залишків шляхом їх фрагментації та подальшої дисперсії і трансформації в наземній екосистемі [30], а отже на швидкість кругообігу речовини та вивільнення зольних хімічних елементів [12]. Це перш за все такі представники мезофауни - типові сапрофаги, як дощові черв'яки [21; 23], двопарноногі багатоніжки [2], мокриці [14], а також окремі представники мікрофауни - орибатидні кліщі [27; 31].

Завдяки трофометаболічній діяльності дощових черв'яків їх грунтові викиди - копроліти - можуть розташовуватися як на поверхні грунту, так і в його товщі, в окремих випадках формуючи цілі копролітові грунтові горизонти 3 новими специфічними біологічними, фізичними і фізико-хімічними властивостями. Представники дощових черв'яків живуть у грунті та утворюють у ньому довгі трубчасті ходи. Копроліти дощових черв'яків являють собою збагачену вуглецем і азотом суміш мінерального субстрату з органічною речовиною та відкладаються ними на поверхні землі. Копроліти також містять гумінові речовини (гумінові кислоти і їх солі - гумати), які роблять їх водостійкими, водоємними, відносно стійкими до механічного впливу [22; 29]. Таким чином, дощові черв'яки структурують грунт, роблять його повітропроникненим, збагаченим живильними речовинами і в кінцевому рахунку за сприятливих умов - родючим. На значення дощових черв'яків у процесі формування грунту одним із перших натуралістів указав наприкінці XIX століття Чарльз Дарвін.

Отже, оцінка ступеня впливу дощових черв'яків на певні компоненти екосистеми, зокрема впливу трофо-метаболічної активності дощових черв'яків на буферну здатність грунтів рекреаційних зон на території мегаполісів на при- 
кладі міських парків, являє науковий і практичний інтерес. Мета дослідження 3'ясувати внесок грунтових новоутворень зоогенного походження (копролітів дощових черв'яків) у буферну здатність урбогрунту на ділянках з насадженням клена гостролистого в межах паркової зони на території м. Дніпро.

У широкому розумінні буферна здатність характеризує енергетичний потенизіал трунту, щзо зумовлює мобілізацію (вивільнення) і іммобілізацію (депонування) того чи іншого елемента родючості [16]. Частіше під буферністю розуміють здатність грунту протистояти змінам його актуальної реакції під впливом різних факторів. Це так звана кислотно-основна буферність, або рН-буферність [10; 16]. Різні грунти мають різну буферність, наприклад, для піщаних грунтів і грунтів підзолистого ряду характерна значно менша буферність проти кислот порівняно з глинистими та суглинистими грунтами або грунтами, збагаченими органічною речовиною [13]. Переважна кількість наукових робіт з вивчення буферної здатності грунтів має сільськогосподарську спрямованість $[9 ; 16 ; 28]$, або вивчення буферної здатності різних генетичних типів грунтів і не пов'язані з грунтовозоологічною складовою [1; 11]. Повністю відсутні відомості про участь грунтових сапрофагів у формуванні та підтримці буферних властивостей міських грунтів під деревними насадженнями у зонах рекреації, оскільки буферні механізми грунту розглядалися науковцями тільки в системі зовнішні впливи - трунт - рослина. Поза увагою залишилася роль тварин - екосистемних «інженерів» як природного чинника стабілізації родючості грунту та його елементарних складових на антропогенно змінених територіях, зокрема в умовах мегаполіса, на прикладі буферної здатності урбогрунту.

Матеріали і методи досліджень. Польовий матеріал відібрано протягом 2016 року на ділянці з кленом гостролистим (Acer platanoides L.) на території міського парку «Зелений гай» (м. Дніпро). Парк «Зелений гай» розташований між видовищно-спортивним комплексом «Метеор» і проспектом О. Поля в межах привододільно-балкового типу ландшафтів правого корінного берега р. Дніпро у Рибальській балці, де у минулому зростав природний байрачний Монастирській ліс. На основі проведених рекогносцировочних грунтово-геоботанічних досліджень установлено, що грунтовий покрив парку належить до категорії антропогенноповерхнево-перетворених грунтів - урбогрунтів [4; 32] та частково зберіг природну структуру. Грунти парку є потенційно лісопридатними для зростання деревночагарникової рослинності. У межах парку сформовані газони відсутні. Практично всі квітники втратили своє функціональне призначення. На окремих ділянках квітників сформувався масовий спонтанний підріст деревно-чагарникових видів.

3 метою визначення впливу екскреторної діяльності сапрофагів на прикладі дощових черв'яків (Lumbricidae) на рН-буферну здатність грунтів паркової зони були зібрані зразки грунту і копролітів. Зразки грунтів відбирали з глибини 0-10 см. Свіжі копроліти дощових черв'яків відібрані на поверхні грунту в зеленому деревному насадженні з клена гостролистого (Acer platanoides L.).

Визначення кислотно-основної буферності грунту і його новоутворень - копролітів дощових черв'яків - засновано на встановленні зміни величини рН унаслідок додавання до них слабких розчинів кислот або лугів. Для визначення буферної здатності копролітів і урбогрунтів застосовано метод Арреніуса [17]. За результатами вимірювань величини актуальної кислотності наводять графік, на якому за абсцисою вказують кількість мілілітрів доданої кислоти (або лугу), а за ординатою - відповідні їм значення рН. Одержані криві графіка дозволяють оцінити буферність досліджених грунтів і грунтових викидів (копролітів) за "площею буферності" в області кислотного і лужного інтервалів навантажень, яка визначається як площа між кривою титрування грунту (дослідний зразок) і піску (еталон, контроль) [8] і яку виражають в умовних квадратних сантиметрах. Площу буферності розраховували за формулою Сімпсона [6; 8]. Вимірювання акту- 
альної кислотності грунтового розчину (pH) безбуферного субстрату (прожареного піску) і дослідних зразків проводили у триразовій повторності. Експериментальні дані оброблені статистично. Розраховували середнє арифметичне, його стандартну помилку, достовірну різницю середніх за критерієм Стьюдента [3].

Результати i ïx обговорення. Для дослідженого урбогрунту на території парку «Зелений гай» в насадженні клена гостролистого зміни рН грунтових зразків і грунтових новоутворень зоогенного походження (копролітів дощових черв'яків) у кислотному і лужному діапазонах одержано такі результати. Так, у ході додавання кислотного компонента (від 1,5 до 3,0 мл) актуальна кислотність верхнього гумусованого шару урбогрунту переходить від слабколужної реакції грунтового розчину $(7,15)$ через умовно нейтральну до слабкокислої $(5,12)$, у той час як копроліти, маючи вихідну умовно нейтральну реакцію $(6,86)$, також набули слабкокислої (5,83 від додавання 3,0 мл кислоти), а надалі розвинули кислу реакцію в ході додавання 6,0 мл кислотного компонента. У процесі додавання більших порцій кислотного продукту (від 4,5 до 9 мл) реакція грунтового розчину зразків цього грунту і копролітів якісно не однакова - кисла і сильнокисла для гумусованого шару урбогрунту і кисла для копролітів, зібраних з поверхні даного урбогрунту. У процесі додавання до зразків урбогрунту дослідженої ділянки парку невеликого об'єму розчину лугу (1,5 мл) реакція грунтового розчину верхнього гумусованого шару урбогрунту змінюється від вихідної нейтральної до лужної (7,05 і 8,32 відповідно), а копролітів - від нейтральної до слабколужної. Якщо в подальшому продовжувати додавати більші порції лугу (від 4,5 до 9 мл), то грунт розвиває сильнолужну реакцію (від 9,49 до 10,55), а копроліти - лужну (від 8,95) і сильнолужну (від 9,53 до 9,92).

Візуалізуємо криві буферності в кислотному діапазоні для урбогрунту (верхній гумусований шар урбогрунту), грунтових новоутворень зоогенного походження (копроліти дощових черв’яків), відібраних на території міського парку «Зелений гай» в деревному насадженні клена гостролистого та для безбуферного субстрату (рис. 1). Розташування кривих титрування досліджуваних зразків у цьому діапазоні свідчить про те, що площа буферності копролітів дощових черв'яків більша, ніж площа буферності верхнього гумусованого шару дослідженого грунту парку.

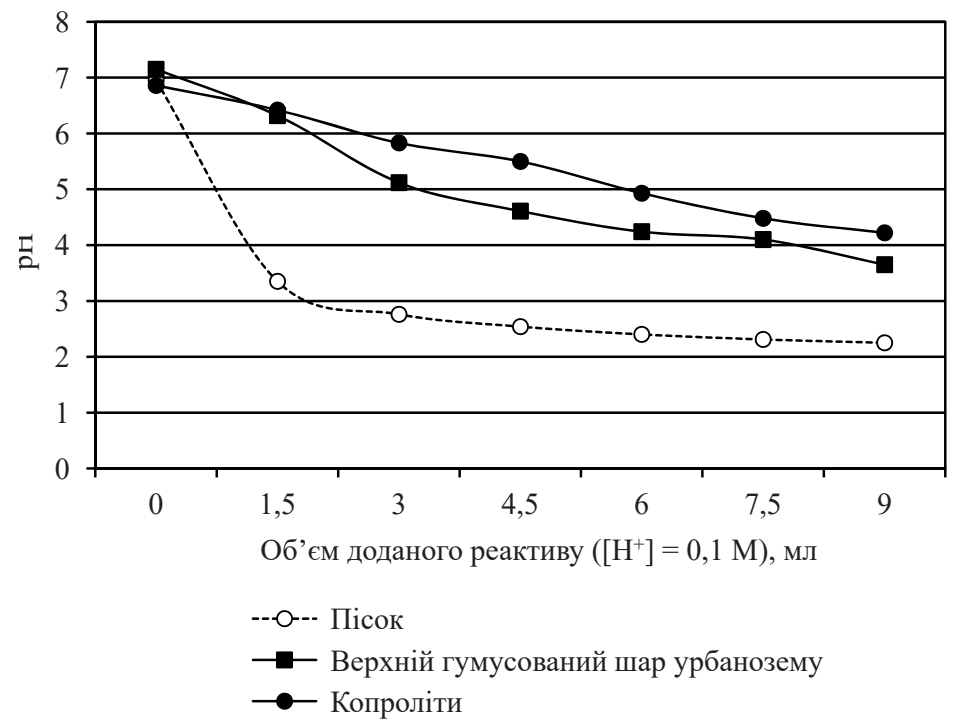

Рис. 1. Крива буферності (кислотне плече) для зразків урбогрунту (верхній гумусований шар) і копролітів дощових черв'яків, відібраних на території парку в умовах мегаполісу та безбуферного суб́страту 
На основі одержаних результатів візуалізуємо криві буферності в лужному діапазоні для урбогрунту (верхній гумусований шар), грунтових новоутворень зоогенного походження (копроліти дощових черв'яків), відібраних на території міського парку «Зелений гай» в деревному насадженні клена гостролистого, та для безбуферного субстрату (рис. 2). Розташування кривих титрування досліджуваних зразків (крива буферності копролітів знаходиться нижче, ніж крива буферності грунту) свідчить про те, що площа буферності копролітів перевищує площу буферності верхнього шару урбогрунту.

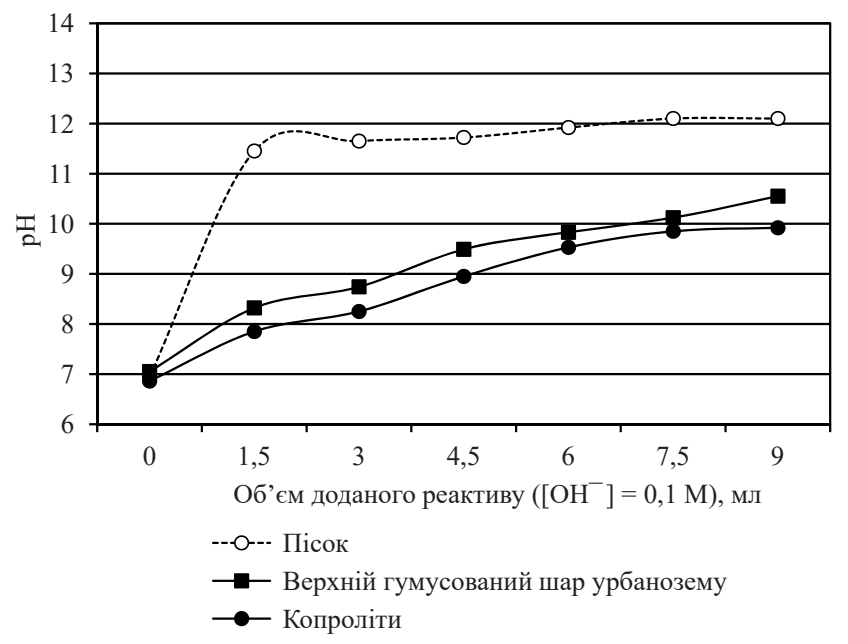

Рис. 2. Крива буферності (лужне плече) для зразків урбогрунту (верхній гумусований шар) і копролітів дощових черв'яків, відібраних на території парку в умовах мегаполісу, та безбуферного субстрату

У табл. 1 наведено площу буферності паркового урбогрунту (верхній гумусований шар) і грунтових новоутворень (копроліти дощових черв'яків). Сумарна площа буферності копролітів статистично достовірно більша, ніж загальна площа буферності верхнього гумусованого шару урбогрунту. При цьому однаковий внесок досягається як за рахунок буферності копролітів у кислотному, так і лужному інтервалах.

Таблиия 1

Кількісна оцінка показників буферної здатності для грунту в насадженні клена гостролистого на території міського парку «Зелений гай» (верхній гумусований

шар урбогрунту) і грунтових новоутворень (копроліти дощових черв'яків)

\begin{tabular}{|l|c|c|c|}
\hline \multirow{2}{*}{$\begin{array}{c}\text { Інтервал } \\
\text { зовнішнього впливу }\end{array}$} & \multicolumn{2}{|c|}{ Площа буферності, см² } & Внесок копролітів у буферну ємність \\
\cline { 2 - 4 } & урбогрунт & копроліти & \% \\
\hline Кислотний & $18,66 \pm 0,21$ & $22,94 \pm 0,31^{*}$ & 22,9 \\
\hline Лужний & $20,41 \pm 0,33$ & $24,17 \pm 0,48^{*}$ & 18,4 \\
\hline $\begin{array}{l}\text { Кислотно-лужний } \\
\text { (сумарний) }\end{array}$ & $39,07 \pm 0,38$ & $47,11 \pm 0,43^{*}$ & 20,6 \\
\hline
\end{tabular}

Примітка. ${ }^{*}$ - достовірна різниця середніх з рівнем значущості $\leq 0,001$.

Підсумовуючи вищенаведене, зазначимо, що стан грунтового покриву озеленених територій мегаполісу, зокрема міських парків, має велике значення для стійкого функціонування рослинного покриву та міського середовища в цілому. Одним із природних механізмів, який позитивно впливає на оптимізацію техногенно-порушених грунтів, до яких належать і міські парки - це середовищепе- 
ретворювальна активність дощових черв'яків як типових представників функціональної групи «екосистемних інженерів». Рийна та трофометаболічна функції дощових черв'яків - суттєвий чинник родючості грунту. Грунт, який пройшов через травний тракт черв'яка, набуває вигляду сферичних або витягнутих грудок землі - копролітів. У процесі риття нір дощовими черв'яками і проходження грунтової маси через їх кишківник та перетворення її у копроліти відбуваються помітні зміни фізичних, фізико-хімічних та хімічних властивостей грунту, які обумовлюють його родючість - здатність грунту забезпечити рослини всіма необхідними факторами та умовами для їх нормального росту й розвитку. Серед властивостей грунту саме буферність визначає процеси депонування або вивільнення елементів родючості (насамперед - хімічні елементи мінерального живлення, продуктивна волога, тепло). Оскільки представники дощових черв'яків істотно впливають як на трофні, вологісні, аеральні, агрегативні, санітарно-детоксикозні, продуктивні функції грунту, то їх активність обумовлює буферну здатність відносно того чи іншого елемента родючості. Отже, трофометаболічна активність таких представників сапротрофного блоку зооценозу, як дощові черв'яки (Lumbricidae), впливає на головний компонент наземних екосистем - грунт, його буферну здатність, яка $\epsilon$ невід’ємною складовою потенціалу родючості.

Висновки. У процесі вивчення екологічного впливу трофометаболічної активності сапрофагів в урбаноземах у насадженні клена гостролистого на теритоpiї міського парку «Зелений гай» в умовах мегаполісу (м. Дніпро) встановлено, що зоогенні грунтові новоутворення (копроліти дощових черв'яків) змінюють буферні властивості грунтів. Результати проведеного нами експерименту свідчать, що кислотно-основна буферна ємність копролітів представників Lumbricidae статистично достовірно вища, ніж вихідного грунту у кислотному інтервалі на $22,9 \%$, у лужному - на 18,4 \%, у сумарному кислотно-лужному відношенні - на $20,6 \%$. Така пертинентна функція дощових черв'яків в умовах мегаполісу на території рекреації в парковій зоні міста Дніпро сприяє позитивним змінам екологічного стану урбогрунтів, натуралізації едафотопу зеленого насадження у складних умовах мегаполіса. Таким чином, ефективність відновлення урбогрунту під час збагачення їх копролітами дощових черв'яків зростає, екологічна якість урбогрунтів поліпшується, спостерігається гальмування негативних впливів в умовах антропотехногенезу на території мегаполіса, а трофометаболічна (сумісно з рийною) активність цих тварин є потужним фактором екологічної реабілітації урбогрунтів на території мегаполіса.

\section{Бібліографічні посилання}

1. Гамкало 3. Г. Роль органічного удобрення в оптимізації кислотно-основних властивостей сірого лісового грунту західного Лісостепу України. Агрохімія і трунтознавство. 2005. № 66. С. 53-58.

2. Гудим Н. Г. Сезонна динаміка чисельності Brachyiulus jawlowskii (Diplopoda, Julidae) на арені р. Дніпро. Вісник Дніпропетровського ун-ту. Біологія, екологія. 2016. 24 (2). P. 489-494.

3. Лакин Г. Ф. Биометрия. Москва: Высш. шк., 1990. 352 с.

4. Лебедева И. И. Классификационное положение и систематика антропогеннопреобразованных почв. Почвоведение. 1993. № 9. С. 98-106.

5. Мавлютова О. С. Роль парков в жизни города. Экология. Безопасность. Жизнь. 1997. № 4. C. 249-250.

6. Маркушевич А. И. Площади и логарифмы. Москва: Наука; Гл. ред. физ.-мат. лит., 1979.64 с.

7. Мірзак $\boldsymbol{O}$. $\boldsymbol{B}$. Досвід дослідження грунтів великих промислових центрів степової зони (на прикладі м. Дніпропетровська). Грунтознавство. 2001. Т. 1, № 1-2. С. 87-92.

8. Надточий П. П. Определение кислотно-основной буферности почв. Почвоведение. 1993. № 4. С. 34-39. 
9. Назырова Ф. И., Гарипо Т. Т. Кислотно-основная буферность зональных типов почв южного Приуралья в агротехногенных условиях. Вестник Оренбургского гос. Ун-та. 2011. № 6 (125). С. 147-156.

10. Орлов Д. С., Орлов Д. С., Садовникова Л. К., Суханова Л. И. Химия почв. Москва: Высш. шк., 2005. 558 с.

11. Позняк С. П., Гамкало М. З. Кислотно-основная буферность буроземов Украинских Карпат. Почвоведение. 2001. № 6. С. 660-669.

12. Покаржевский А. Д. Геохимическая экология наземных животных. Москва: Наука, 1985.304 с.

13. Почвоведение: учеб. для ун-тов: в 2-х ч. / Г. Д. Белицина (и др.); под ред. В. А. Ковды, Б. Г. Розанова. Москва: Высш. шк., 1988. Ч. 1: Почва и почвообразование. $400 \mathrm{c}$.

14. Стриганова Б. Р. Питание почвенных сапрофагов. Москва: Наука, 1980. 244 с.

15. Строганова $\boldsymbol{M}$. $\boldsymbol{H}$. Городские почвы: генезис, систематика и экологическое значение на примере г. Москвы: автореф. дис. ... докт. биол. наук. Москва, 1998. 71 с.

16. Трускавецький $\boldsymbol{P}$. $\boldsymbol{C}$. Буферна здатність грунтів та їх основні функції. Харків: Нове слово, 2003. 225 с.

17. Физико-химические методы исследования почв. Под ред. Н. Г. Зырина, Д. С. Орлова. Москва: МГУ, 1980. 382 с.

18. Хохрякова $\boldsymbol{A}$. I. Грунти міст: особливості генезису, класифікації та діагностики. Вісник Одеського наиіонального університету. Сер.: Географічні та геологічні науки. 2016. Т. 21. Вип. 1. С. 110-125.

19. Экология города: учеб. пособ. Под ред. проф. В. В. Денисова. Москва: ИКЦ «МарТ», Ростов н/Д: Издательский центр «МарТ», 2008. 832 с.

20. Экология города: Учебник. Под общ. ред. проф. Ф. В. Стольберга. Киев: Либра, 2000. $464 \mathrm{c}$.

21. Berke $\boldsymbol{S}$. $\boldsymbol{K}$. Functional groups of ecosystem engineers: a proposed classification with comments on current issues. Integrative and Comparative Biology. 2010.50 (2). P. 147157.

22. Earthworms and their influence on soil structure and infiltration // Earthworm ecology and biogeography in North America / A. D. Tomlin, M. J. Shipitalo, W. M. Edwards, R. Protz. P. F. Hendrix (Ed.). Boca Raton: CRC Press, 1995. P. 159-183.

23. Earthworms as key actors in self-organized soil systems. P. Lavelle, S. Barot, M. Blouin, T. Decaens, J. J. Jimenez, P. Jouquet; Editors K. Cuddington, J. Byers, W. Wilson, A. Hastings. Ecosystem engineers: Plants to protists. Burlington (MA): Academic Press, 2007. P. 77-106.

24. Ecosystem Engineers in a self-organized soil: A review of concepts and future research questions. P. Lavelle, A. Spain, M. Blouin, G. Brown, T. Decaëns et all. Soil Science. 2016. $181(3 / 4)$. P. 91-109.

25. The action of an animal ecosystem engineer: Identification of the main mechanisms of earthworm impacts on soil microarthropods. Pedobiologia. 2010. Vol. 53, Iss. 6. P. 343-352.

26. Environmental aspects of the effect of earthworm (Lumbricidae, Oligochaeta) tropho-metabolic activity on the $\mathrm{pH}$ buffering capacity of remediated soil (steppe zone, Ukraine). Y. L. Kul'bachko, O. O. Didur, I. M. Loza, O. E. Pakhomov, O. V. Bezrodnova. Biology Bulletin. 2015. 42 (10). P. 899-904.

27. Gormsen D., Hedlund K., Huifu W. Diversity of soil mite communities when managing plant communities on set-aside arable land. Applied Soil Ecology. 2006. 31 (1-2). P. $147-158$.

28. Hamkalo Z. Differential acid-base buffering of soil as yardstick of ecological efficiency of an organic component of fertilizings of agrophytocenosises. Грунтознавство. 2004. Т. 5. № 3-4. C. 43-46.

29. Schrader S., Zhang H. Earthworm casting: Stabilization or destabilization of soil structure? Soil Biology and Biochemistry. 1997. Vol. 29, Issues 3-4. P. 469-475.

30. Sjursen H., Michelsen A., Holmstrup M. Effects of freeze-thaw cycles on microarthropods and nutrient availability in a sub-Arctic soil. Applied Soil Ecology. 2005. 28. P. 79-93.

31. Smrž Ja., Norton R. A. Food selection and internal processing in Archegozetes longisetosus (Acari: Oribatida). Pedobiologia. 2004. 48 (2). P. 111-120. 
32. Soils of Moscow and urban environment. M. Stroganova, A. Myagkova, T. Prokof'eva, I. Skvortsova. Москва: Изд-во ПАИМС, 1998. 166 с.

33. Structure of litter macrofauna communities in poplar plantations in an urban ecosystem in Ukraine. L. I. Faly, T. M. Kolombar, E. V. Prokopenko, O. Y. Pakhomov, V. V. Brygadyrenko. Biosystems Diversity. - 2017. - 25 (1). - C. 29-38.

Надійшла до редколегії 12.11.2017 p.

УДК $574.4: 598.2$

О. Л. Пономаренко

Дніпровський національний університет імені Олеся Гончара

\title{
СЕЗОННА ДИНАМІКА КОНСОРТИВНИХ ЗВ'ЯЗКІВ ПТАХІВ 3 ДУБОМ ЗВИЧАЙНИМ (QUERCUS ROBUR)
}

Досліджено міжсезонну динаміку консортивних зв'язків птахів в індивідуальних консорціях дуба звичайного. Проаналізовано показники загального бюджету часу птахів на одне ядро консорції, його динаміку по сезонах, видовий склад та чисельність птахів-консортів протягом року. Виявлено, що система консортивних зв'язків птахів протягом року на віргінільному дубі має стохастичний характер. На молодому генеративному дубі, протягом року домінують трофічні взаємодії. На старому генеративному дубі, крім інтенсивних трофічних зв'язків, птахи протягом року реалізують також численні топічні зв'язки. Стабільність системи консортивних зв'язків птахів з дубом звичайним зростає в напрямку від віргінільного до старого генеративного.

Ключові слова: дуб звичайний, птахи, консорція, міжсезонна динаміка.

\section{А. Л. Пономаренко \\ Днепровский национальный университет имени Олеся Гончара}

\section{СЕЗОННАЯ ДИНАМИКА КОНСОРТИВНЫХ СВЯЗЕЙ ПТИЦ С ДУБОМ ЧЕРЕШЧАТЫМ (QUERCUS ROBUR)}

Исследована межсезонная динамика консортивных связей птиц в индивидуальных консорциях дуба черешчатого. Проанализированы показатели общего бюджета времени птиц на одно ядро консорции, их динамика по сезонам, видовой состав и численность птиц-консортов в течение года. Выявлено, что система консортивних связей птиц в течение года на виргинильном дубе имеет стохастический характер. На молодом генеративном дубе в течение года доминируют трофические взаимодействия. На старом генеративном дубе, кроме интенсивных трофических связей, птицы в течение года реализуют также многочисленные топические связи. Стабильность системы консортивних связей птиц с дубом черешчатым растет в направлении от виргинильного к старому генеративному.

Ключевые слова: дуб черешчатый, птицы, консорция, межсезонная динамика.

\author{
O. L. Ponomarenko \\ Oles Honchar Dnipro National University
}

\section{SEASONAL DYNAMICS OF BIRDS KONSORTIA'S INTERACTIONS WITH OAK (QUERCUS ROBUR)}

The interseasonal dynamics of birds consortia interactions in individual oak consortia was investigated. The birds daily time budget (DTB) and their interseasonal dynamics, species and abundance of birds-consorts during the year were analyzed. The material of

(C) О. Л. Пономаренко, 2017 